\title{
Treatment of Hypolimnion Water on Mineral Aggregates as the Second Step of the Hypolimnetic Withdrawal Method Used for Lake Restoration
}

\author{
Justyna Łożyńska ${ }^{1}$, Julita A. Dunalska ${ }^{1, *} \oplus$, Agnieszka Bańkowska-Sobczak ${ }^{2} \mathbb{C}$, Li Zhang ${ }^{3}$ \\ and William J. Mitsch ${ }^{3}$ (I)
}

check for updates

Citation: Łożyńska, J.; Dunalska, J.A.; Bańkowska-Sobczak, A.; Zhang, L.; Mitsch, W.J. Treatment of Hypolimnion Water on Mineral Aggregates as the Second Step of the Hypolimnetic Withdrawal Method Used for Lake Restoration. Minerals 2021, 11, 98. https://doi.org/ $10.3390 / \min 11020098$

Academic Editors: Binoy Sarkar, Lei Wang and Raj Mukhopadhyay Received: 27 November 2020 Accepted: 15 January 2021 Published: 20 January 2021

Publisher's Note: MDPI stays neutral with regard to jurisdictional claims in published maps and institutional affiliations.

Copyright: (C) 2021 by the authors. Licensee MDPI, Basel, Switzerland. This article is an open access article distributed under the terms and conditions of the Creative Commons Attribution (CC BY) license (https:// creativecommons.org/licenses/by/ $4.0 /)$.
1 Department of Water Protection Engineering and Environmental Microbiology, University of Warmia and Mazury in Olsztyn, Prawocheńskiego St. 1, 10-719 Olsztyn, Poland; justyna.sienska@uwm.edu.pl

2 Department of Hydraulic Engineering and Applied Geology, Warsaw University of Life Sciences-SGGW, Nowoursynowska 159 St., 02-776 Warsaw, Poland; agnieszka_bankowska@sggw.edu.pl

3 Everglades Wetland Research Park, Florida Gulf Coast University, Naples, FL 43221, USA; lzhang@fgcu.edu (L.Z.); wmitsch@fgcu.edu (W.J.M.)

* Correspondence: julitad@uwm.edu.pl; Tel.: +48-503-168-485

\begin{abstract}
The study aimed to assess the usefulness of mineral aggregates in orthophosphate (OP) removal from hypolimnetic water withdrawn from eutrophic lakes. Two low-cost and easily available reactive materials were tested: lightweight expanded clay aggregate (LECA) and crushed limestone (LS). Their performance regarding OP removal and the effect on the $\mathrm{pH}, \mathrm{Ca}^{2+}, \mathrm{Mg}^{2+}, \mathrm{N}_{-} \mathrm{NO}_{3}$ and $\mathrm{N}-\mathrm{NH}_{4}$ concentrations of treated water were investigated in a column experiment with four-filter beds made of LECA and amended with LS (additions of 0, 25, 50 and 75\% of the bed volume). The highest OP removal ( $>50 \%$ ) was achieved in LECA beds with high ( $75 \%$ by volume) amendments of LS. Neither LECA nor LS distinctly affected the $\mathrm{pH}$ (maximum $\mathrm{pH}$ increase, from 7.1 or 7.2 to 7.6, occurred in the case of the LECA bed). In real-life conditions, it is not feasible to install a full-scale bed made of these mineral aggregates on the outflow from a lake due to the large required size of such a bed. At the operation time set for $30 \mathrm{~d}$, the size of a bed would need to reach between 6113.2 and $12,226.4 \mathrm{~m}^{3}$. The proposed bed should be just one of the elements of an integrated treatment system. Constructions consisting of sorption beds ought to be coupled with adequately designed zones of aquatic vegetation. Three conceptional solutions were proposed for in situ treatment of the withdrawn water, differing in arrangement and construction of the potential sorption bed. Application of such solutions should be regarded as a substantial improvement of Olszewski's method, as it can mitigate the pollution of downstream ecosystems.
\end{abstract}

Keywords: P removal; mineral aggregates; LECA; limestone; hypolimnion withdrawal; Olszewski's method

\section{Introduction}

Many lake restoration methods have been developed and implemented [1,2], including the technical engineering methods and the ecological engineering solutions $[3,4]$, often referred to as "methods supporting the proper restoration of waterbodies". The restoration of waterbodies is always an arduous challenge and is not always successful [5-7]. Therefore, new solutions for sustaining and improving the water quality should develop into ecosystem biotechnology.

The simplest and the least expensive method of lake restoration is to withdraw water from the lake's hypolimnion directly through a pipeline and discharge it into a downstream water body, usually a small river or a creek. The principle of the method is that deoxygenated and nutrient-rich water is removed from the lake together with organic residues settling from the trophogenic zone. Such a technology was developed by Prof. Olszewski and implemented for the first time in Lake Kortowskie (Poland) in 1956 [8,9]. 
In Poland, Olszewski's method has also been used to restore Lake Rudnickie in Grudziądz and the Pławniowice Reservoir [10]. Due to its simplicity and low cost, this lake restoration solution attracts the most interest in Europe and Northern America [11-13]. However, a serious drawback is the pollution of the receiving river with nutrients [14-16]. A long-term research project dealing with Lake Kortowskie has confirmed that the total phosphorus concentrations at the lake's outflow in the summer varied within $0.37-1.73 \mathrm{mg} \mathrm{P} \cdot \mathrm{dm}^{-3}$, and the levels of orthophosphates (OP) ranged from 0.30 to $0.65 \mathrm{mg} \mathrm{PO}_{4}{ }^{3-} \mathrm{dm}^{-3}$ [17], whereas mean concentration of ammonium during pipe operation reached up to $1.16 \mathrm{mg}$ $\mathrm{N}-\mathrm{NH}_{4} \cdot \mathrm{dm}^{-3}$ [18]. Thus, attempts to reduce these nontarget effects on the downstream ecosystems are needed.

This can be gained by in situ treatment of the hypolimnetic water withdrawn from a lake before it reaches the receiving water body. For this purpose, hydrophyte methods, based on the biological processes used so far in wastewater treatment [19] could be employed. Microorganisms, as well as water and moisture-loving plants (hydrophytes) growing in properly designed facilities (earthen filters or ponds), are flooded periodically or permanently with wastewater. Such systems are highly effective in removing organic substances and ammonium nitrogen (over a 90\% removal success) [20]. On the other hand, the reduction of phosphorus concentration by an accumulation in plant tissues can reach $10-40 \%[21,22]$. Despite the numerous advantages of hydrophyte wastewater treatment facilities, the solution presents a major drawback, i.e., a large area it needs to cover to be efficient [23]. An alternative option is to couple biological processes with sorption in specially designed abiotic-biotic systems involving mineral aggregates [24,25]. The application of mineral aggregates can help to reduce substantially the area dedicated to water pretreatment while simultaneously raising the efficiency of phosphorus removal. Currently, sorption materials of natural origin are widely used in wastewater treatment technologies, which results from their high effectiveness in the removal of pollutants and low costs $[26,27]$. An example is an aggregate called lightweight expanded clay aggregate (LECA), consisting mainly of clay minerals. With its high sorption capacity, water-permeability and porosity, LECA are employed in hydrophyte wastewater treatment facilities with both vertical and horizontal wastewater flows [28-30]. An additional benefit is that the surface of LECA can be overgrown with a biofilm, where the development of microorganisms favors the nitrification and denitrification processes, as well as dephosphatation. This property endows LECA with the capacity to remove effectively both phosphorus and nitrogen [27,31-33]. Carbonate minerals, such as dolomite and calcite, are another group of sorption materials widely used in the removal of phosphorus from water. They are applied as crushed carbonate rocks (dolomite or limestone, LS) to fill sorption beds in hydrophyte wastewater treatment plants and in earthen and plant systems developed to purify wastewater $[27,34,35]$, river waters [36,37] and in biogeochemical barriers used in the pretreatment of groundwater $[38,39]$. The research conducted thus far has focused on the assessment of the sorption capacity of small-grained $(<10 \mathrm{~mm})$ mineral aggregates at high-concentration OP solutions, usually found in wastewater $\left(5-200 \mathrm{mg} \cdot \mathrm{dm}^{-3}\right)$ [40-43]. Only a few studies $[44,45]$ have assessed adsorption capacity of mineral aggregates under relatively low OP concentrations typically found in freshwater ecosystems. Therefore, information about the removal of OP under lake-specific OP concentrations and ionic composition is still limited. On the other hand, it is also extremely important to assess the efficiency of the removal of pollutants under dynamic flow conditions, as the efficiency of phosphorus removal in static studies (batch type) is not necessarily repeatable in semitechnical or technical flow-through experiments [29,46].

Hence, the objective of this study was to determine the possibilities of using mineral aggregates in different volumetric ratios in sorption beds to remove phosphorus compounds from hypolimnetic water discharged to a downstream water body. Our analysis included LECA and calcite-based aggregate (limestone) with grain sizes of 10-30 mm. Dynamic flow column experiments were performed using natural water from the lake's hypolimnion. The research focused on the effectiveness of the process and on the impact 
the applied sorption materials had on the $\mathrm{pH}$ and the concentrations of $\mathrm{Ca}^{2+}, \mathrm{Mg}^{2+}, \mathrm{N}^{-\mathrm{NO}_{3}}$ and $\mathrm{N}^{-\mathrm{NH}_{4}}$ in treated water. The results can provide valuable information that may allow us to improve Olszewski's method; in addition to which, they might serve as a basis for developing innovative engineering solutions for the betterment of the surface water quality. The reported study responds to the tasks defined in the Water Framework Directive 2000/60/EC of 25 October 2000, which obligates all European Union member states to achieve a good environmental status of all waters until 2027.

\section{Materials and Methods}

\subsection{Reactive Materials}

Two reactive materials were used in the study: LECA and limestone (LS), both having grain sizes of 10-30 mm. As already mentioned, these aggregates were chosen from among four low-cost and easy available materials tested in a previous study for OP removal from hypolimnetic water in static sorption experiments [44]. According to the X-ray diffraction (XRD) analysis, LECA consists mainly of clay minerals (91\%), mostly aluminum silicates, including smectite, illite and chlorite, accompanied by quartz, calcite and dolomite. The material is characterized by a very high porosity of $78 \%$ and surface area of $51.2 \mathrm{~m}^{2}$ $\mathrm{g}^{-1}$ (determined with the $\mathrm{N}_{2}$ adsorption (BET) method). Limestone is crushed sedimentary rock, originating from deposits in Southwestern Poland, and it contained mainly calcium carbonate in the form of calcite (96\%). Its surface area was $1.3 \mathrm{~m}^{2} \mathrm{~g}^{-1}$. The main metallic components of LECA are silicon, aluminum and calcium, whereas limestone contains mainly calcium (Table 1 ).

Table 1. The $\mathrm{pH}$ and compositions of the reactive materials (\%) (manufacturer data) (LS: limestone and LECA: lightweight expanded clay aggregate.

\begin{tabular}{|c|c|c|c|c|c|c|c|c|c|c|c|c|}
\hline $\begin{array}{l}\text { Reactive } \\
\text { Mate- } \\
\text { rial }\end{array}$ & $\mathrm{pH}$ & $\mathrm{CaO}$ & $\mathrm{MgO}$ & $\mathrm{Fe}_{2} \mathrm{O}_{3}$ & $\mathrm{Al}_{2} \mathrm{O}_{3}$ & $\mathrm{SO}_{3}$ & $\mathrm{SiO}_{2}$ & $\mathrm{MnO}$ & $\mathrm{Na}_{2} \mathrm{O}$ & $\mathrm{K}_{2} \mathrm{O}$ & $\mathrm{TiO}_{2}$ & $\mathrm{P}_{2} \mathrm{O}_{5}$ \\
\hline LECA & 8.2 & 10.76 & 3.20 & 8.31 & 15.82 & 0.04 & 56.26 & 0.01 & 0.59 & 3.58 & 0.64 & 0.23 \\
\hline LS & 7.5 & 53.33 & 0.61 & 0.27 & 0.38 & 0.13 & 2.60 & 0.01 & - & - & - & - \\
\hline
\end{tabular}

\subsection{Experimental Design}

Four columns made of PVC (diameter of $0.07 \mathrm{~m}$ and length of $1 \mathrm{~m}$ ) were filled with reactive materials (total volume of the materials was $0.004 \mathrm{~m}^{3}$ ). One column was filled with LECA only (variant 1, V1), and three columns were filled with LECA previously mixed with LS (V2-V4) (Figure 1). The addition of LS made up 25\%, 50\% and 75\% of the total bed volume (V2-V4, respectively), which corresponded to LECA and the LS volumes to volume ratios of 3:1, 1:1 and 1:3, respectively. Hypolimnetic water continuously flowed onto the filter bed under constant flow conditions (the water discharge was regulated using a valve in the column outlet (Figure 1)). The water discharge in the column inlet was $0.017 \mathrm{~m}^{3} \mathrm{~h}^{-1}$. The experiment was performed in a temperature-controlled room at $10{ }^{\circ} \mathrm{C}$. The effluent from each column was sampled at $28 \mathrm{~min}$ steps as long as the recorded reduction rate of the phosphate concentrations was $\geq 10 \% \pm 1 \%$. The following parameters were measured in the effluent: the $\mathrm{pH}$ and concentrations of phosphate, calcium, magnesium, nitrates and ammonium. 

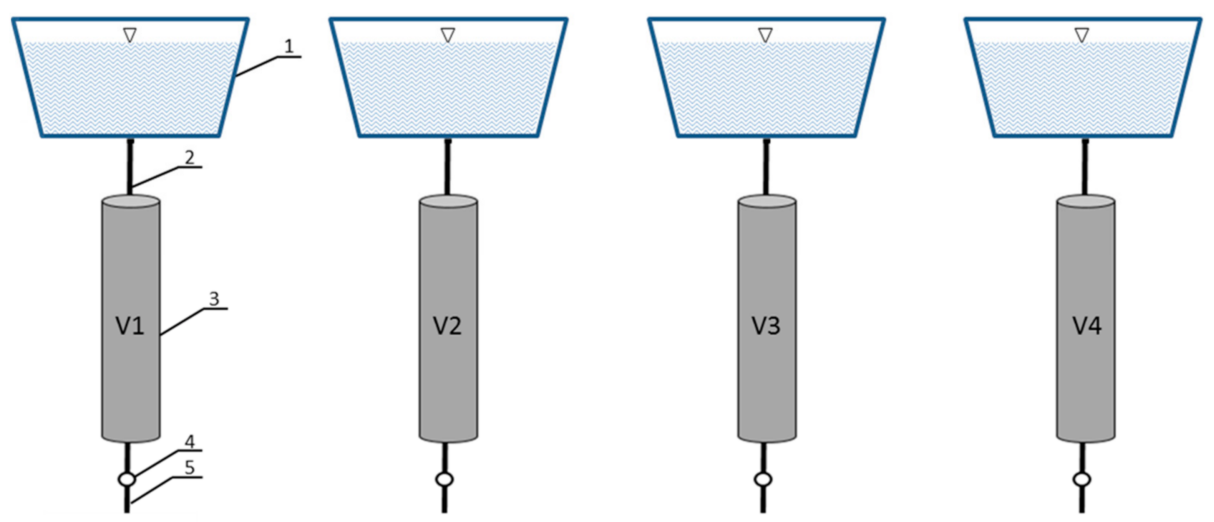

Figure 1. Setup of the column experiment: (1) hypolimnetic water reservoir, (2) alimenting pipe, (3) column bed, (4) regulating valve and (5)-discharge tube. V1: column filled with lightweight expanded clay aggregate (LECA) only, and V2-V3: columns filled with LECA and limestone (LS) (volumetric share of LS: $25 \%, 50 \%$ and $75 \%$, respectively).

\subsection{Hypolimnetic Water}

Hypolimnetic water was sampled from the outlet of the hypolimnion withdrawal pipeline operating in Lake Kortowskie, a water body situated in Olsztyn, Poland (Figure 1). The sampling took place in late July 2017, as the middle of summer represents a period of the highest near-bottom nutrient concentrations in stratified lakes due to organic matter sedimentation and decay, as well as internal nutrient loading from sediments. Hypolimnetic water sampled for the experiments was characterized by low temperature, nearly neutral $\mathrm{pH}$ and OP concentrations of $0.41-0.46 \mathrm{mg} \mathrm{PO}_{4}{ }^{3-} \mathrm{dm}^{-3}$ (Table 2).

Table 2. Properties of the hypolimnetic water used in the experiments.

\begin{tabular}{|c|c|c|c|c|}
\hline \multirow[b]{2}{*}{ Parameter } & \multicolumn{4}{|c|}{ Variant } \\
\hline & $\begin{array}{c}\text { V1 } \\
(100 \% \text { LECA) }\end{array}$ & $\begin{array}{c}\text { V2 } \\
(75 \% \text { LECA + } \\
25 \% \text { LS) }\end{array}$ & $\begin{array}{c}\text { V3 } \\
(50 \% \text { LECA + } \\
50 \% \text { LS })\end{array}$ & $\begin{array}{c}\text { V4 } \\
(25 \% \text { LECA + } \\
75 \% \text { LS })\end{array}$ \\
\hline Temperature $\left({ }^{\circ} \mathrm{C}\right)$ & 9.9 & 10.1 & 10.0 & 9.9 \\
\hline $\mathrm{pH}$ & 7.13 & 7.17 & 7.08 & 7.07 \\
\hline $\mathrm{PO}_{4}{ }^{3-}\left(\mathrm{mg} \mathrm{dm}^{-3}\right)$ & 0.46 & 0.43 & 0.41 & 0.44 \\
\hline $\mathrm{N}-\mathrm{NO}_{3}\left(\mathrm{mg} \mathrm{dm}^{-3}\right)$ & 0.06 & 0.07 & 0.07 & 0.07 \\
\hline $\mathrm{N}-\mathrm{NH}_{4}\left(\mathrm{mg} \mathrm{dm}^{-3}\right)$ & 1.85 & 1.95 & 1.94 & 1.81 \\
\hline $\mathrm{Ca}^{2+}\left(\mathrm{mg} \mathrm{dm}^{-3}\right)$ & 67.0 & 67.3 & 67.0 & 67.4 \\
\hline $\mathrm{Mg}^{2+}(\mathrm{mg} \mathrm{dm}-3)$ & 10.6 & 11.1 & 10.9 & 11.3 \\
\hline
\end{tabular}

\subsection{Chemical Analysis}

The $\mathrm{pH}$ was measured potentiometrically using a standard multimeter (MultiLine P4, WTW, Weilheim, Germany). The OP concentration was determined using the molybdenum blue method according to the standard protocols (PN-EN ISO 6878) at the wavelength of $880 \mathrm{~nm}$ and optical path length of $50 \mathrm{~mm}$ on a Nanocolor UV/Vis spectrophotometer (Macherey-Nagel, Düren, Germany). Ionic concentrations $\left(\mathrm{Ca}^{2+}, \mathrm{Mg}^{2+}, \mathrm{NO}_{3}{ }^{-}\right.$and $\left.\mathrm{NH}_{4}{ }^{+}\right)$ in the hypolimnetic water were determined by high-performance liquid chromatography (HPLC) chromatography (Shimadzu analyzer, Prominence System, Tokyo, Japan).

\section{Results}

\subsection{Orthophosphate (OP) Removal Efficiency}

OP retention was recorded on all column beds (Figure 2). Irrespective of the experimental variant, the highest reduction of OP concentration took place in the very initial stage of the experiment (within $0.5 \mathrm{~h}$ (28 min; Figure 2). Afterwards, the OP concentration 
slowly increased, reaching the assumed saturation level (minimum OP removal rate of $10 \pm 1 \%$ ) after about $2-7.5 \mathrm{~h}$, depending on the column bed filling (Figure 2 and Table 3 ).

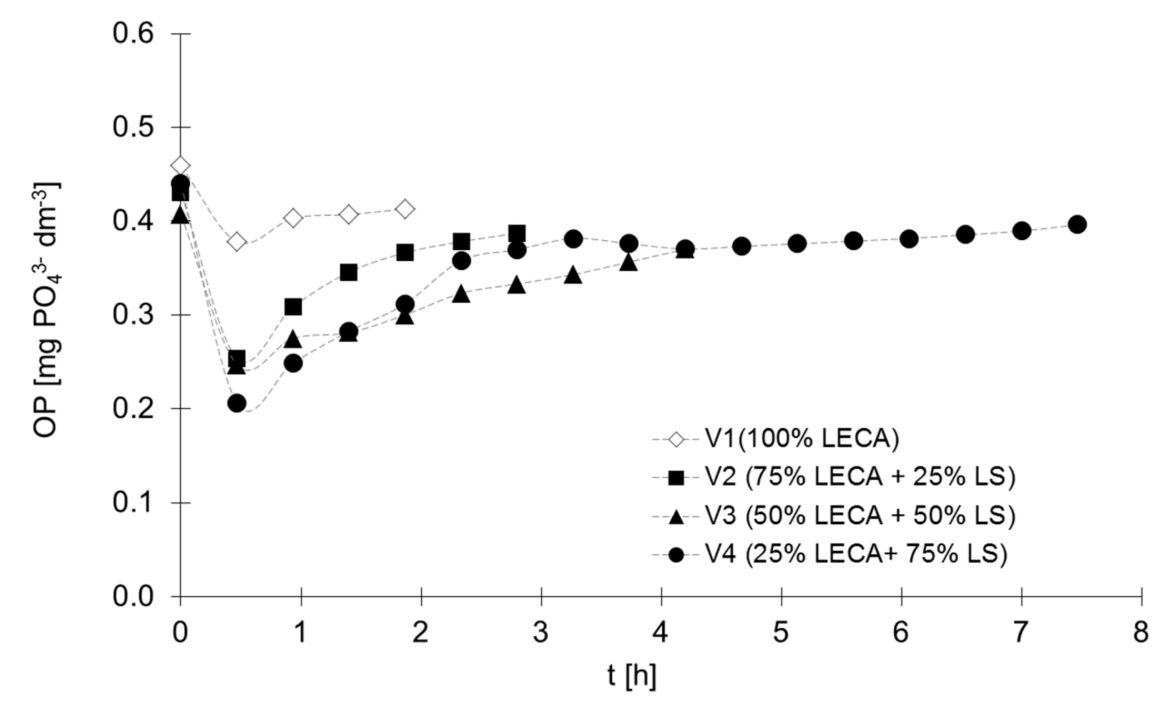

Figure 2. Orthophosphate (OP) removal from the hypolimnetic water during treatment on column beds (LS: limestone); dashed lines were used for better visibility of the trend. Results were presented for the time of effective sorption (OP removal rate of $\geq 10 \pm 1 \%$ ).

Table 3. Parameters of the orthophosphate (OP) removal onto LECA/LS beds (effective sorption defined as a $\mathrm{OP}$ removal rate of $\geq 10 \pm 2 \%$ ).

\begin{tabular}{cccc}
\hline $\begin{array}{c}\text { Variant of Bed } \\
\text { Composition }\end{array}$ & $\begin{array}{c}\text { Time of Effective } \\
\text { Sorption }\end{array}$ & $\begin{array}{c}\text { Volume of Water } \\
\text { Treated }\left(\mathbf{d m}^{\mathbf{3}}\right)\end{array}$ & $\begin{array}{c}\text { P Removed } \\
\left.\mathbf{( m g ~ P O}_{\mathbf{4}} \mathbf{3}^{-}\right)\end{array}$ \\
\hline V1 (100\% LECA) & $1 \mathrm{~h} 52 \mathrm{~min}$ & 335 & 19.7 \\
V2 (75\% LECA + 25\% LS) & $2 \mathrm{~h} 48 \mathrm{~min}$ & 508 & 45.5 \\
V3 (50\% LECA + 50\% LS) & $4 \mathrm{~h} 12 \mathrm{~min}$ & 762 & 70.1 \\
V4 (25\% LECA + 75\% LS) & $7 \mathrm{~h} 28 \mathrm{~min}$ & 1348 & 122.3 \\
\hline
\end{tabular}

The OP removal rate increased with the increasing LS volume in the bed. After $0.5 \mathrm{~h}$ of the column operation, the OP concentration dropped to $0.38 \mathrm{mg} \mathrm{PO}_{4}{ }^{3-} \mathrm{dm}^{-3}$ in the column filled with LECA only (V1), which corresponded to the OP removal rate of $17.8 \%$ (Figure 2). Within the same time, in beds amended with LS (V2, V3 and V4), the decrease was 2.2-3 times higher and accounted for $41.0 \%, 39.3 \%$ and $53.2 \%$, respectively (the achieved OP concentrations were $0.25,0.25$ and $0.21 \mathrm{mg} \mathrm{PO}_{4}{ }^{3-} \mathrm{dm}^{-3}$; Figure 2 . Thus, no important difference was detected between variants V2 and V3 (25\% and 50\% LS), whereas the further addition of LS $(75 \%, \mathrm{~V} 4)$ resulted in an obviously higher sorption. After a longer time of the bed operation, the OP concentrations continued to increase, indicating a decreasing OP removal (Figure 2). However, in the column V3 (50\% of LS), this decrease in OP removal was slower as compared to the other beds amended with LS (V2 and V4), and thus, a slightly higher removal of OP was recorded after two to three hours in V3 (50\% LS) than in V4 (75\% LS), which is contrary to the pattern observed after 0.5 h (Figure 2). At the same time, the OP removal on column V3 (50\% LS) was distinctly higher as compared to V2 (25\%LS) (the OP removal rates after about two to three hours were 16-26\% and 9-15\%, respectively; Figure 2).

In the column filled with LECA only (V1), an OP removal rate of at least $10 \%$ was maintained for $1 \mathrm{~h} 52 \mathrm{~min}$ (Figure 2 and Table 3). During this time, the LECA bed (V1) treated $335 \mathrm{dm}^{3}$ of the hypolimnetic water, which corresponded to a total load of $152 \mathrm{mg} \mathrm{PO}_{4}{ }^{3-}$ and removed $12.9 \%$ of this load (19.7 $\mathrm{mg} \mathrm{PO}_{4}{ }^{3-}$ ) (Table 3$)$. In the case of columns with LECA and limestone (V2-V4), the duration of the effective OP removal ( $\geq 10 \%)$ was 1.5, 2.3 and 
four times longer, respectively, than on the LECA bed (V1). The most efficient column V4 (the highest addition of limestone) treated $1348.4 \mathrm{dm}^{3}$ of the hypolimnetic water, which corresponded to a load of $593 \mathrm{mg} \mathrm{PO}_{4}{ }^{3-}$ and fixed $20.6 \%$ of the load $\left(122.3 \mathrm{mg} \mathrm{PO}{ }^{3-}\right)$.

After the removal rate dropped below $10 \%$, all the beds continued to reduce the OP concentration in the hypolimnetic water by about 8\% (V1 and V2 for at least four hours, whereas V3 - for six hours). This is a valuable observation for a potential field construction of such beds, as it shows prolonged OP fixation.

\section{2. $\mathrm{pH}$ and Concentration of $\mathrm{Ca}^{2+}$ and $\mathrm{Mg}^{2+}$ in the Hypolimnetic Water after Treatment}

All the tested filter beds raised the $\mathrm{pH}$ of the hypolimnetic water, but the $\mathrm{pH}$ remained nearly neutral to slightly alkaline throughout the entire experiment (Figure 3). The most pronounced $\mathrm{pH}$ change was recorded during the initial stage of the experiment (after $0.5 \mathrm{~h}$ of the bed operation): the $\mathrm{pH}$ increased from 7.1-7.2 (before treatment) to 7.5 (V1), 7.6 (V2), 7.3 (V3) and 7.4 (V4). However, the $\mathrm{pH}$ dropped to the level of 7.2-7.4 during the continued operation of the filter beds (Figure 3).

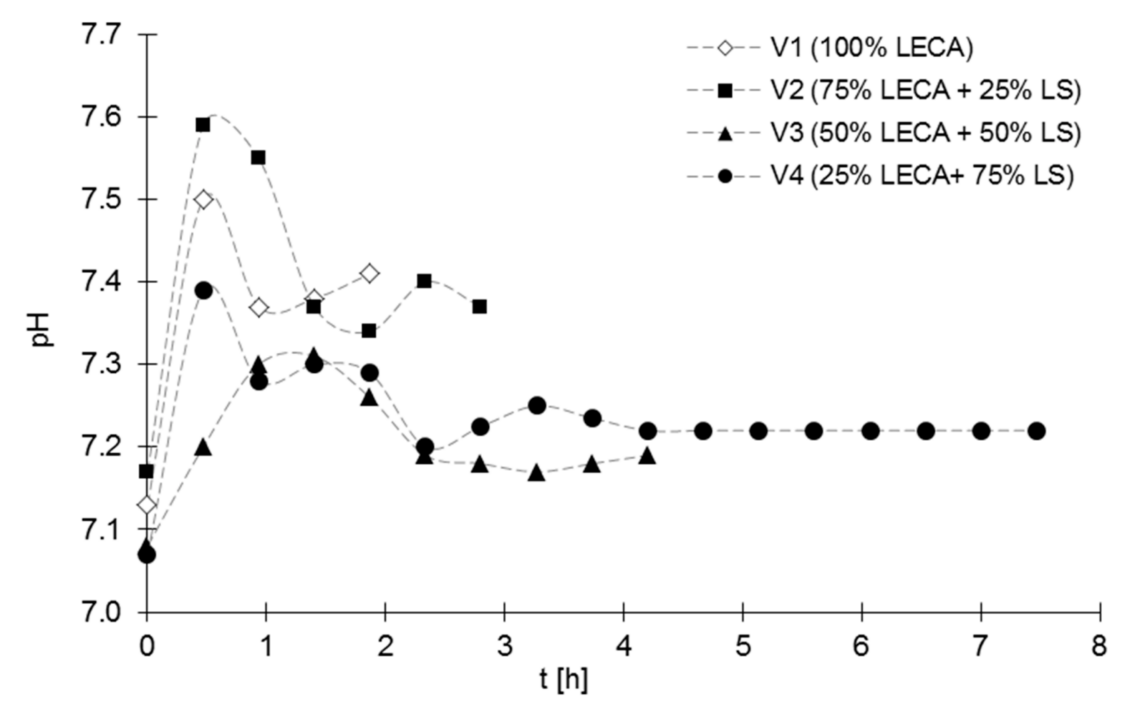

Figure 3. The $\mathrm{pH}$ of the hypolimnetic water during treatment on the column beds (LS: limestone); dashed lines were used for better visibility of the trends. Results were presented for the time of effective sorption (OP removal rate of $\geq 10 \pm 1 \%$ ).

The treatments on the LECA and LECA/LS beds also affected the ionic composition of the hypolimnetic water (Figure $4 \mathrm{a}, \mathrm{b}$ ). Similar to the $\mathrm{pH}$, the contents of the calcium and magnesium increased sharply during the initial stage of the experiment. After $0.5 \mathrm{~h}$, the concentrations of $\mathrm{Ca}^{2+}$ and $\mathrm{Mg}^{2+}$ rose by $22.7 \mathrm{mg} \mathrm{Ca}^{2+} \mathrm{dm}^{-3}(33.9 \%)$ and $16.1 \mathrm{Mg}^{2+} \mathrm{dm}^{-3}$ $(145.0 \%)$ after treatment on the LECA bed (V1), as compared to untreated water. The supply of $\mathrm{Ca}^{2+}$ was much higher in the columns enriched with LS $(51.1 \%, 55.4 \%$ and $65.0 \%$ in the variants V2, V3 and V4, respectively) and increased with the increasing share of this material in the bed volume (Figure 3). A contrary effect was recorded for magnesium: the increase in its concentration was the higher the lower the LS volume. For example, after $0.5 \mathrm{~h}$, the concentration of $\mathrm{Mg}^{2+}$ after treatment on the columns $\mathrm{V} 2$ and V3 was $150 \%$ and $73 \%$ higher (as compared to the nontreated water, respectively), whereas, after treatment on V4, the difference was only $4 \%$.

During the subsequent bed operation, the concentrations of $\mathrm{Ca}^{2+}$ and $\mathrm{Mg}^{2+}$ tended to decrease and remain relatively stable, although some slight fluctuations took place. The concentrations of both cations showed very similar trends in all variants and remained in the range typically found in freshwater. 

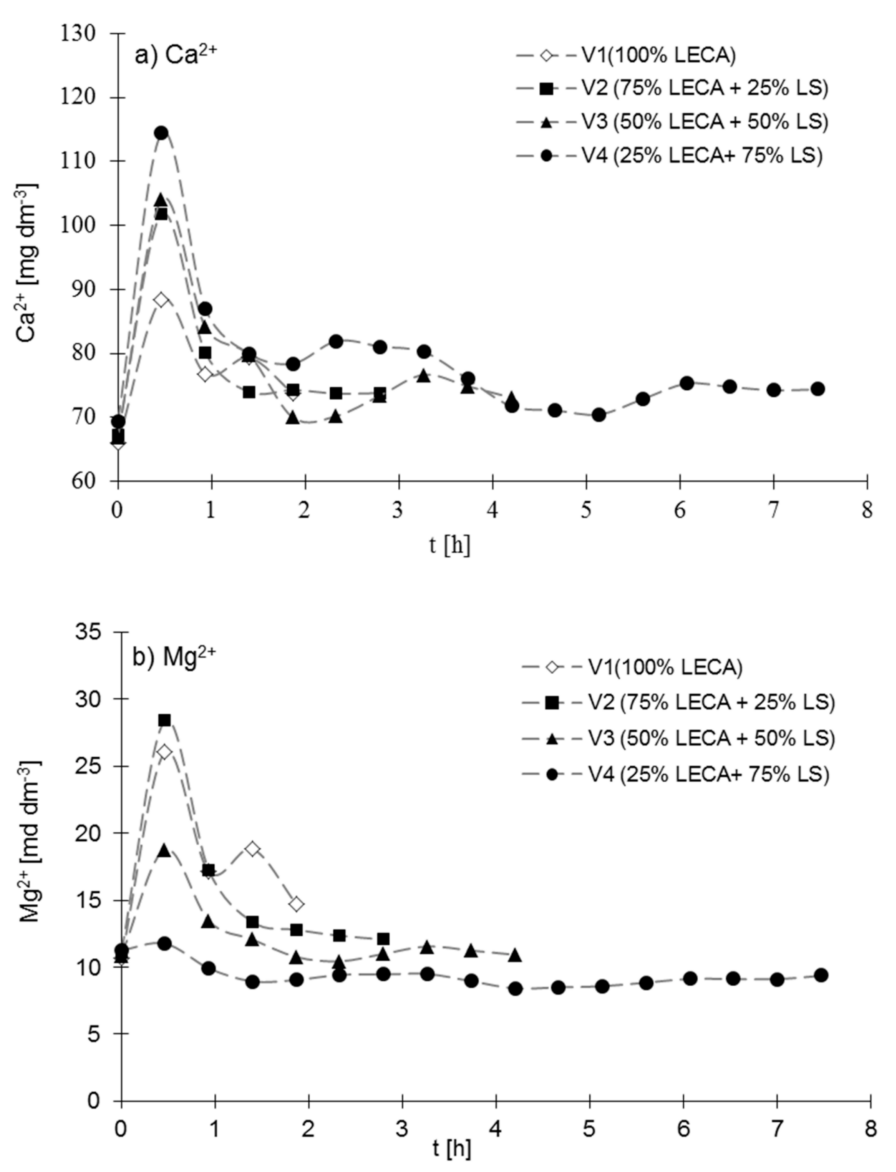

Figure 4. Concentrations of $\mathrm{Ca}^{2+}(\mathbf{a})$ and $\mathrm{Mg}^{2+}(\mathbf{b})$ in the hypolimnetic water during the treatments on the column beds (LS: limestone); dashed lines were used for better visibility of the trend. Results were presented for the time of effective sorption (OP removal rate of $\geq 10 \pm 1 \%$ ).

\subsection{Inorganic Nitrogen in the Hypolimnetic Water after Treatment}

After treatment on the column filled with LECA only (V1), the concentration of the nitrates sharply dropped after $0.5 \mathrm{~h}$ and further increased, reaching nearly the level of not treated water (Figure 5a), whereas the concentrations of $\mathrm{N}^{-N_{4}}{ }_{4}$ clearly increased throughout the time of the column operation (Figure $5 b, c$ ). The concentrations of $\mathrm{N}^{-N_{4}}$ at the end of the column operation were $10.5 \%$ and $9.8 \%$ (respectively) higher as compared to the water not subjected to treatment.

After contact with column beds containing $25 \%$ and $75 \%$ LS (V2 and V4) the same trend can be seen for the nitrates, with a sharp drop after just $0.5 \mathrm{~h}(28 \mathrm{~min})$ of the treatment and a subsequent increase (Figure 5a). In the variant V3 (50\% LS), the concentrations of the nitrates initially also decreased (reaching a level about two times lower as compared to the other columns with LS; Figure 5a) but remained relatively stable afterwards (Figure 5a). However, for ammonium, treatments on columns with LS resulted in an opposite change as compared to the column filled with LECA only (V1). In the initial stage of the column operation (up to $1 \mathrm{~h} 24 \mathrm{~min}$ for V2, $1 \mathrm{~h} 52 \mathrm{~min}$ for V3 and $2 \mathrm{~h} 20 \mathrm{~min}$ for V4), $\mathrm{N}^{-\mathrm{NH}_{4}}$ slightly decreased (by $7.6-10.6 \%, 16.9-20.3 \%$ and $6.9-12.1 \%$, respectively) as compared to the hypolimnetic water without treatment (Figure 5b). Afterwards, the concentration of $\mathrm{N}-\mathrm{NH}_{4}$ started to increase but remained lower as compared to the hypolimnetic water before treatment $(\mathrm{V} 2,25 \% \mathrm{LS})$, remained relatively stable $(\mathrm{V} 3,50 \% \mathrm{LS})$ or further dropped (V4, 75\% LS). 

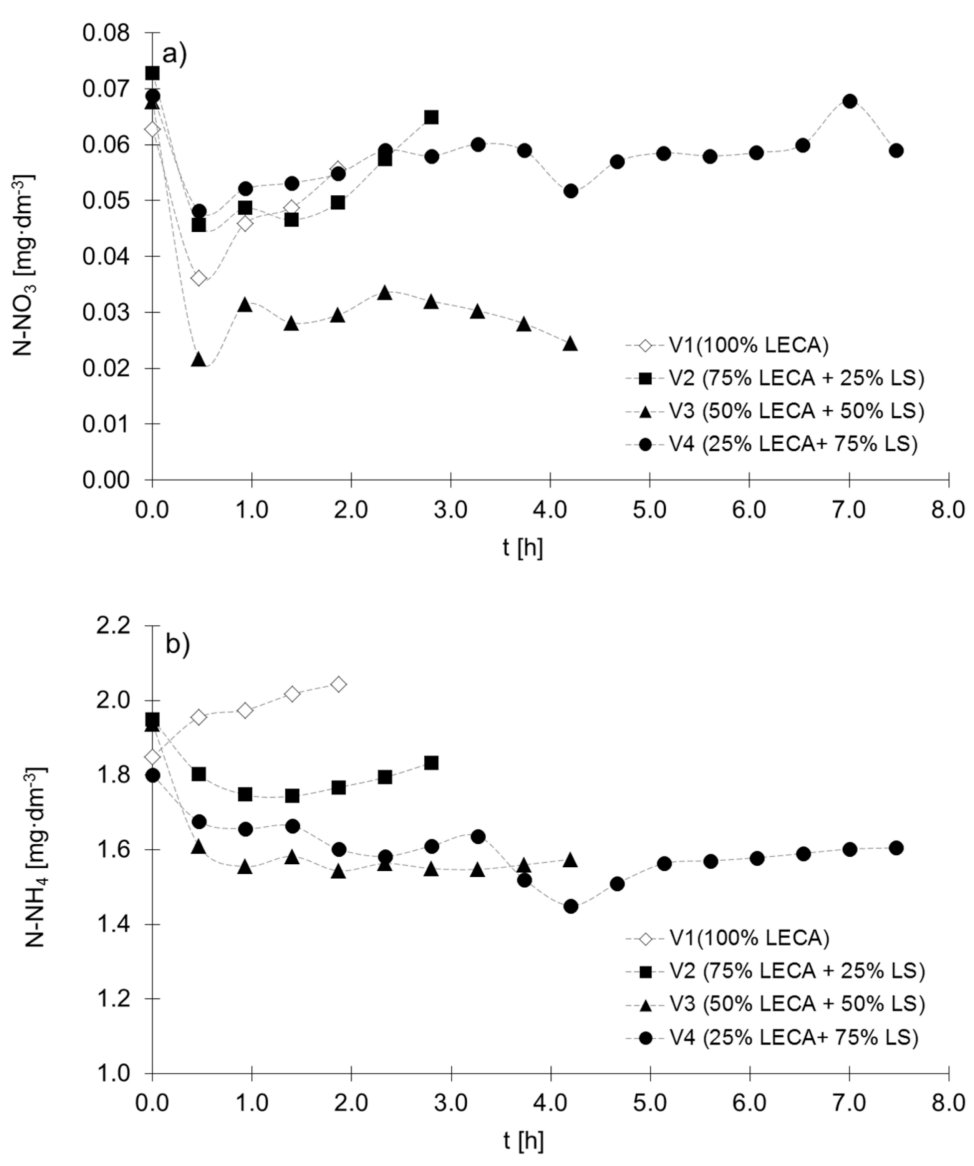

Figure 5. Concentrations of nitrates (a) and ammonium (b) in the hypolimnetic water during the treatments on column beds (LS: limestone); dashed lines were used for better visibility of the trend. Results were presented for the time of effective sorption (OP removal rate of $\geq 10 \pm 1 \%$ ).

\section{Discussion}

\subsection{OP Removal Efficiency}

The results showed that a similar pattern of OP removal in time was observed irrespectively on the composition of the sorption bed, with the most pronounced P sorption in the very initial stage of the experiment (up to $0.5 \mathrm{~h}$ ) and its continued decrease during the column operations (Figure 2). This indicates that the surface areas of the reactive materials were gradually exhausted, leading to a drop in the OP fixation. Interestingly, at the beginning of experiment, a substantial rise in the $\mathrm{pH}$ and concentrations of $\mathrm{Mg}^{2+}$ and $\mathrm{Ca}^{2+}$ also took place (Figures 3 and 4 ), which points at the flushing of calcium and magnesium from the alkaline components of the sorbents. The increase in $\mathrm{pH}$ from nearly neutral to slightly alkaline must have reduced, to some extent, the sorption of OP onto LECA, as its adsorption ability decreases with the alkalization of the solution [44,45] due to the change in the ligand type being replaced with OP [45]. In the case of the same LECA as investigated in the current study, a pH rise from 7.0 to 7.5 at the temperature of $10^{\circ} \mathrm{C}$ resulted in a $10 \%$ lower OP fixation [44]. An increase in $\mathrm{pH}$ in the range observed after $0.5 \mathrm{~h}$ could also affect the performance of LS, as it generally enhances OP sorption onto calcite, most likely by changes in phosphate speciation $[46,47]$. Furthermore, the adsorption of OP onto LS was probably positively affected by the elevated concentrations of $\mathrm{Ca}^{2+}$ and $\mathrm{Mg}^{2+}$, as they also enhance the OP adsorption onto calcite [47-49]. Therefore, it can be concluded that, during the initial stage of the experiment, the highest OP removal in the beds with LS was mainly due to the highly reactive surface available for adsorbing phosphate ions and was supported by $\mathrm{pH}$ rise and the $\mathrm{Ca}^{2+} / \mathrm{Mg}^{2+}$ supply. In the further stages of the experiments, OP retention decreased with time, which, in case of LS, was not 
only due to the gradual saturation of the reactive surface with phosphate ions, but also due to the decreasing $\mathrm{pH}$ and $\mathrm{Ca}^{2+} / \mathrm{Mg}^{2+}$ concentrations. Naturally, these new components (additional pool of $\mathrm{Ca}$ and $\mathrm{Mg}$ ) were fast removed from the system due to the continuous water flow. However, random measurements of the $\mathrm{pH}$ and concentrations of $\mathrm{Ca}^{2+}$ and $\mathrm{Mg}^{2+}$ revealed that these parameters were substantially raised already after one minute of the bed operation (data now shown). Thus, as water flowed down the column, its $\mathrm{pH}$ and $\mathrm{Ca} / \mathrm{Mg}$ contents gradually increased due to contact with the sorbents, which must have affected the sorption taking place in the lower part of the column (that was reached by water with an already raised $\mathrm{pH}$ and metal concentrations).

Generally, the performance of columns in OP retention was the better the higher the volume of LS in the sorption bed (Figure 2). However, enhancement of the OP removal due to the LECA replacement with LS was not proportional to the LS addition. This can be seen when comparing variants V2 and V3 (25\% and $50 \%$ of LS), as only slight difference in OP removal were observed (39\% versus $41 \%$, accordingly; Figure 2 ). One likely reason for that is the relatively low $\mathrm{pH}$ observed in the variant V3 (Figure 3). Only a minor increase in OP removal in V3 as compared to V2 in the initial stage of the experiment could therefore be due to a relatively low $\mathrm{pH}$ in $\mathrm{V} 3$ (in $\mathrm{V} 2$, the OP retention was probably enhanced thanks to the distinct $\mathrm{pH}$ increase, whereas this supporting effect was not involved in V3). Moreover, only a minor rise in the $\mathrm{Ca}^{2+}$ concentration was recorded when the LS share in the bed increased from $25 \%$ to $50 \%$ (V2 versus V3; Figure 4a), showing the same pattern as OP (Figure 2). A relatively low supply of $\mathrm{Ca}^{2+}$ in $\mathrm{V} 3$ could be another reason for an only slightly increased OP retention in $\mathrm{V} 3$ as compared to $\mathrm{V} 2$ during the initial stage of the experiment.

A relatively low $\mathrm{pH}$ and low $\mathrm{Ca}^{2+}$ leaching in $\mathrm{V} 3$ as compared to $\mathrm{V} 2$ during the initial stage of the experiment $(0.5 \mathrm{~h})$ suggests that, despite the higher addition of LS in V3 (50\% of LS by volume), only slightly more calcite was dissolved as compared to V2 (25\% of LS by volume), which might result from the nonhomogeneous water flow through the bed (preferential paths). This is another factor potentially explaining an only minor increase in OP removal at a higher share of LS in V3 as compared to V2 (Figure 2). However, changes in the $\mathrm{pH}$ during the continued bed operation show that the $\mathrm{pH}$ rise in $\mathrm{V} 3$ was somehow delayed as compared to the other variants (the highest $\mathrm{pH}$ value was recorded after 1-1.5 $\mathrm{h}$ in V3 and after $0.5 \mathrm{~h}$ in the other variants) (Figure 3). Hence, it can be assumed that, at this time, the remaining volume of the column was available for the flowing water (which did not get into contact with the water earlier), resulting in a $\mathrm{pH}$ change, although this is not confirmed by $\mathrm{Ca}^{2+}$ (Figure 4a). The same reason is likely to be valid for the slower decrease in OP removal in $\mathrm{V} 3$ as compared to the other variants (Figure 2).

Irrespectively of the above-described observations, the research outcomes showed that LECA and LS, if applied in an adequate volumetric ratio, can be an effective sorption material for the removal of OP from hypolimnetic water. The addition to LS making up $25 \%, 50 \%$ and $75 \%$ relative to LECA improved the effectiveness of the OP removal from hypolimnetic water by $4.8 \%, 16.4 \%$ and $19.2 \%$, respectively, since the moment the presumed saturation of the bed was achieved $(\leq 10 \%)$ (Table 3$)$. LS added to the sorption bed also resulted in a three- to five-fold longer operating time compared with the time attained by the LECA bed (Table 3). This confirms that the addition of LS to highly porous LECA can distinctly enhance the effectiveness of the OP removal and longevity of the filter bed. The reason for that is the slightly higher adsorption capacity of the LS. Both materials were tested in our previous study [44]. In hypolimnion water, the maximum adsorption capacity of the LS was about 18\% higher as compared to the LECA [44]. Drizo et al. [50] also reported higher P sorption onto the limestone as compared to the LECA. However, the presence of LECA in a filter bed is important because of its high porosity and hydraulic conductivity, ensuring efficient water flow through the system [26]. Thus, a combined bed made of LECA and LS at a volumetric ratio of 1:3 is recommended as a treatment method for the purification of hypolimnetic water.

Despite the high effectiveness of the removal of OP in the experimental study, a fully dimensional bed filled with a LECA-LS mixture in real-life conditions is not possible to 
design because of its large size. Our calculations revealed that, for the hydraulic conditions employed, i.e., a water discharge of $0.017 \mathrm{~m}^{3} \mathrm{~h}^{-1}$, retention time of $28 \mathrm{~min}$ and bed volume of $0.004 \mathrm{~m}^{3}$, the OP removal rate was from 3.18 to $6.36 \mathrm{~g} \cdot \mathrm{m}^{-2} \cdot \mathrm{d}^{-1}$ (depending on the type of bed) [51]. Therefore, at a reduction of the OP concentration from $0.4 \mathrm{mg} \cdot \mathrm{dm}^{-3}$ (concentration determined in the hypolimnetic water) to a value below $0.1 \mathrm{mg} \cdot \mathrm{dm}^{-3}$ at the operation time set for $30 \mathrm{~d}$, the size of the bed would need to reach between 6113.2 and $12,226.4 \mathrm{~m}^{3}$ [51]. For this reason, the removal of nutrients from hypolimnetic water on LECA-LS beds should be just one of the elements in an integrated water pretreatment system. Potential solutions to be applied in the field are discussed in Section 4.4.

\subsection{Effect on $\mathrm{pH}, \mathrm{Ca}^{2+}$ and $\mathrm{Mg}^{2+}$}

For the protection of receiving waters, it is important that LECA/limestone beds do not substantially affect the physiochemical properties of the treated water. The maximum increase in $\mathrm{pH}$ relative to the initial value was 0.4 (V2; Figure 3). It occurred in the first phase of the experiment and was followed by a decreasing tendency (Figure 3), so that the $\mathrm{pH}$ remained approximately the same as in the natural water of the hypolimnion. This is due to the relatively low $\mathrm{pH}$ of the used materials: LECA-8.2 and LS-7.5, and nearly neutral $\mathrm{pH}$ of the hypolimnetic water (7.1-7.2, Table 2). The source of the $\mathrm{pH}$ rise must have been caused by a slight dissolution of the alkaline components of the sorbents bearing $\mathrm{Ca}$ and $\mathrm{Mg}$, as their concentrations also increased (Figure 4), as previously discussed. In general, a higher supply of calcium in the case of LS and magnesium in the case of LECA were observed. This probably reflects the mineral compositions of the mineral aggregates: LS contains about five-fold more calcium than LECA (due to the dominance of calcite), and LECA contains about five-fold more magnesium than LS (Table 1). However, the concentration of magnesium was higher after the treatment of hypolimnetic water on the sorption beds with a higher share of LECA after about $1.5 \mathrm{~h}$ of treatment, whereas in the initial stage of the experiment, it was slightly higher in variant V2 than in V1, despite the lower LECA share in V2 (Figure $4 \mathrm{~b})$. This difference was, however, only minor $(1.7 \mathrm{mg} / \mathrm{L}$ after $0.5 \mathrm{~h}$, of which $0.5 \mathrm{mg} / \mathrm{L}$ was due to the difference in the initial concentrations; Table 2; after $1 \mathrm{~h}$, no actual difference was recorded). This suggests that the replacement of $25 \%$ of LECA with LS by volume (V2,) actually did not change the rate of $\mathrm{Mg}^{2+}$ supply from the sorption bed. One reason for that could be the different solubilities/dissolution rates of the Mg-bearing minerals present in the LECA (mainly clay minerals (smectite, chlorite and illite) and dolomite) and LS (probably Mg-calcite and/or dolomite; only calcite was detected in LS).

This study demonstrated that the $\mathrm{pH}$ and concentrations of calcium and magnesium increased due to the hypolimnetic water treatment on all the sorption beds, mainly during the initial stage of the experiment. As previously discussed, an increased $\mathrm{pH}$ and supply of $\mathrm{Ca}^{2+}$ and $\mathrm{Mg}^{2+}$ can, to some extent, enhance the OP removal efficiency by LS by supporting the adsorptive OP binding onto calcite $[46,47,49]$, but this effect would probably be limited to the initial phase of the bed operation. An increase in $\mathrm{Ca}^{2+}$ concentration due to sorbent dissolution can also contribute to dissolution-induced phosphate precipitation with calcium on the mineral surface, a consequence reported, for example, by Wang et al. [52] and Klasa et al. [53] for calcite surfaces, as the supply of calcium and corresponding $\mathrm{pH}$ increase both enhance the saturation with respect to the calcium phosphates. This process, due to the low solubility of calcium-phosphate phases and their stability under a wide range of environmental conditions $[54,55]$, is believed to improve the long-term performance of P-reactive materials $[26,35,56,57]$. A similar effect can be due to the $\mathrm{Mg}^{2+}$ supply [58]. However, precipitation processes are likely under high OP concentrations, so their importance in the treatment of hypolimnetic water would probably be minor.

The results of our experiments are also valid in terms of the potential applicability of pretreatment systems, especially because numerous studies carried out before on the potential use of P-reactive materials in wastewater pretreatments demonstrated a strong alkalinization of the environment, depending on the applied sorption products. For example, Polonite ${ }^{\circledR}$, which is calcium silicate rock heated at $900{ }^{\circ} \mathrm{C}$, proven to be a highly effective 
$\mathrm{P}$ sorption material, caused an increase in the $\mathrm{pH}$ up to 10.8 in permeable reactive barriers [38] or even up to $>12$ in a wastewater filtration system [59]. Filtralite-P, LECA heated at $1200{ }^{\circ} \mathrm{C}$, raised the $\mathrm{pH}$ to 10.7 [27]. Although these materials are much more efficient in $P$ removal than LECA [60] and LS [38], their highly alkaline properties and strong effects of the $\mathrm{pH}$ of the effluent bring up questions of their applicability in natural water bodies, as that would necessitate an additional solution to decrease the $\mathrm{pH}$ back to the levels of the natural values. Another non-target effect potentially influencing downstream water bodies is the modified composition of the hypolimnetic water in terms of increased concentrations of calcium and magnesium. Higher $\mathrm{Ca}^{2+}$ concentration may contribute to enhanced calcite precipitation in receiving water bodies. As phosphate is co-precipitated with calcite, this process is seen as an important self-purification mechanism in lakes and rivers [61-64].

\subsection{Effect on Inorganic Nitrogen}

Changes in the concentrations of nitrogen compounds did not show a clear dependency on the material filling the column bed, except for the fact that a decrease in the $\mathrm{N}-\mathrm{NH}_{4}$ concentrations took place only after treatment on the beds containing LS (V2-V4; Figure $5 b$ ), whereas they increased after the treatment on the column made of LECA (V1). The highest and stable reduction of ammonium and nitrate concentration was recorded in the column V3 (50\% LS) (Figure 5a,b). Nevertheless, the loss of nitrates was observed for all the columns (Figure 5a).

The hypolimnion water was initially anoxic or hypoxic (some nitrates were present, Table 2). In the initial stage of the experiment, the removal of $\mathrm{N}^{-\mathrm{NH}_{4}}$ by nitrification could be therefore excluded from our experiment, which was confirmed by the fact that the concentrations of $\mathrm{N}^{-\mathrm{NO}_{3}}$ dropped at the same time (Figure 5a,b). The loss of ammonium could have been caused by the anammox process (leading to $\mathrm{NH}_{4}{ }^{+}$oxidation into $\mathrm{N}_{2}$ under anaerobic conditions using nitrites as terminal electron acceptors [65]). The temperature of hypolimnetic water (about $10^{\circ} \mathrm{C}$ ) and its $\mathrm{pH}$ during treatment (7.2-7.6) should not hinder the process, as both laboratory and commercial-scale experiments have proven that this process can occur at lower temperatures, i.e., from $10^{\circ} \mathrm{C}[66]$, and the water $\mathrm{pH}$ within 7.5-8.5 [67]. However, the concomitant depletion of nitrates in the initial stage of the column operation (Figure 5a) suggests that the denitrification could also proceed at the same time.

During the later stage of the experiment an increase in $\mathrm{N}^{-\mathrm{NO}_{3}}$ concentrations was recorded (the exception was column $\mathrm{V} 3$, where $\mathrm{N}^{-\mathrm{NO}_{3}}$ was relatively stable; Figure 5a). This must have been an effect of oxygenation of the hypolimnetic water and resulting $\mathrm{NH}_{4}{ }^{+}$ nitrification. Oxygenation of the hypolimnion water is unavoidable in a treatment system under real-life conditions, so the nitrification of ammonium should be expected. However, the increase in $\mathrm{N}-\mathrm{NO}_{3}$ was much smaller than the loss of $\mathrm{N}^{-\mathrm{NH}_{4}}$ (Figure $5 \mathrm{a}, \mathrm{b}$ ), so also some other factors had to be responsible for the persistent $\mathrm{N}-\mathrm{NH}_{4}$ drop.

The question is why $\mathrm{N}-\mathrm{NH}_{4}$ was lost only after the treatment on LS-containing beds (V2-V4), whereas its concentration slightly increased after the treatment on the column bed made of LECA only (V1) (Figure 5b). This is very surprising, as LECA has been proven to be able to remove $\mathrm{NH}_{4}{ }^{+}$by sorption processes [68]. Moreover, the effect of $\mathrm{LS}$ on $\mathrm{NH}_{4}{ }^{+}$ removal seems to be confirmed also by the fact that the initial decrease in the $\mathrm{N}^{-\mathrm{NH}_{4}}$ concentrations lasted the longer, the higher was the LS share in the column ( $1 \mathrm{~h} 24 \mathrm{~min}$ for V2, $1 \mathrm{~h} 52 \mathrm{~min}$ for V3 and $2 \mathrm{~h} 20 \mathrm{~min}$ for V4 (Figure 5b)). If microbial processes are assumed to dominate in the $\mathrm{N}$ transformations in our experiment, the results suggest that the presence of LS had a somehow promoting effect on the microbial activity. On the other

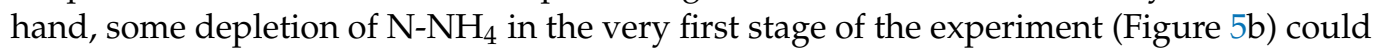
have been due also to the $\mathrm{pH}$ increase as the importance of $\mathrm{NH}_{4}{ }^{+}$decreases in favor of ammonia $\left(\mathrm{NH}_{3 a q}\right)$ as the $\mathrm{pH}$ rises above 7 . However, taking into account that only a slight $\mathrm{pH}$ change took place (from 7.1 or 7.2 (no treatment) to 7.6 (V2), 7.3 (V3) and 7.4 (V4); Figure 3), the $\mathrm{N}-\mathrm{NH}_{4}$ loss by up to $20 \%$ (Figure $5 \mathrm{~b}$ ) could not be related to the $\mathrm{pH}$ rise only (at $\mathrm{pH}=7.5$, ammonia constitutes about $5 \%$ of the ammoniacal species). Moreover, 
that highest loss occurred due to the treatment on the column V3 (50\% LS), and no loss occurred in column V1 (LECA only), where the $\mathrm{pH}$ was very similar to that recorded after the treatments on the other columns (Figure 3).

Thus, the complex mechanism of the observed depletion of ammonium during the bed operation could not be directly explained within this study; still, the results seem to suggest some importance of $\mathrm{LS}$ in $\mathrm{NH}_{4}{ }^{+}$loss, even though the $\mathrm{NH}_{4}{ }^{+}$loss was only slight. The removal of nitrogen compounds on the sorption beds is mainly related to the microbial activity, as the surfaces of aggregates promote the development of a bacterial biofilm [31-33], so an increased efficiency in terms of $\mathrm{N}$ removal can be expected after biofilm development. Nevertheless, even the little and short-term removal of inorganic nitrogen from the treated water, as observed in our study, is important for the protection of the downstream water as water withdrawn from the hypolimnion is usually rich in ammonium.

\subsection{Potential Solutions for the Treatment of Bed Construction in the Field}

As previously stressed, the removal of nutrients from hypolimnetic water in LECALS beds should be just one of the elements in an integrated water pretreatment system. To achieve the prolonged removal of OP, sorption beds should be coupled with systems where vascular plants are used. Numerous studies have identified a group of plants with a high affinity to nitrogen and phosphorus accumulation, such as common reed (Phragmites australis), sweet flag (Acorus calamus), broadleaf cattail (Typha latifolia), acute sedge (Carex acuta), yellow iris (Iris pseudacorus) and reed mannagrass (Glyceria maxima) [39]. The construction of abiotic systems in the form of sorption beds would be used in the form of gabions placed in the river channel receiving hypolimnetic waters directly at the hypolimnion discharge. Below, a few solutions for the implementation are presented.

The placement of gabions longitudinally, along the river/creek banks, would be the easiest solution (Figure 6). Directly at the outlet of the withdrawal pipeline, gabions with high shares of limestone mixed with LECA ( $75 \%$ and $25 \%$, respectively) should be used as filter materials due to their higher sorption capacity, as revealed.

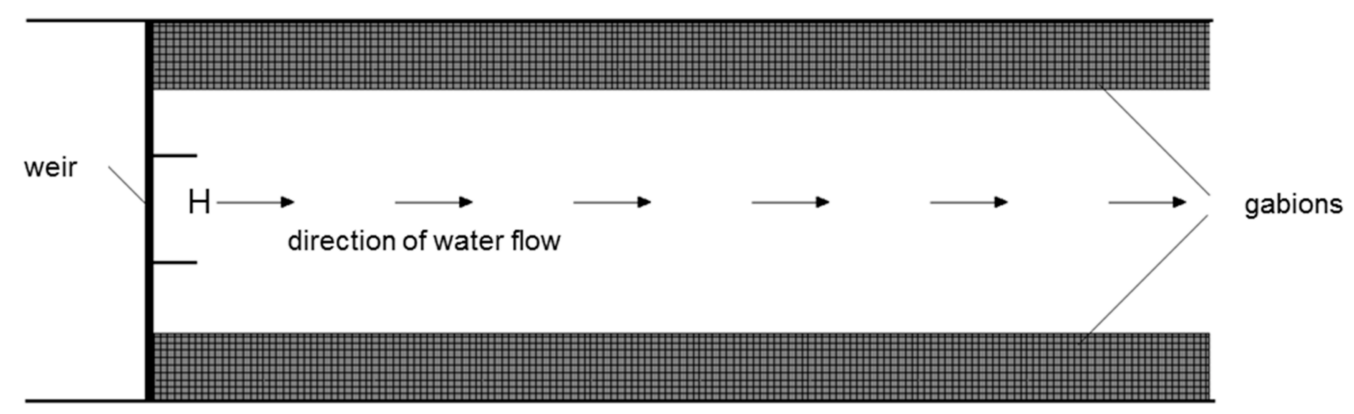

Figure 6. Longitudinal arrangement of a treatment system for hypolimnetic water using reactive materials. H: outlet of the hypolimnion withdrawal pipe.

Another solution would be lying the gabions crosswise in the riverbed (Figure 7). Alternately, the gabions should be placed on both riverbanks. This solution enhances the reactive area of the filter materials and their volume, which, together with a longer retention time, will result in a higher P removal. Limestone and LECA should be involved the same way as proposed for the previous solution, with a higher limestone volume in the front section of the system. 


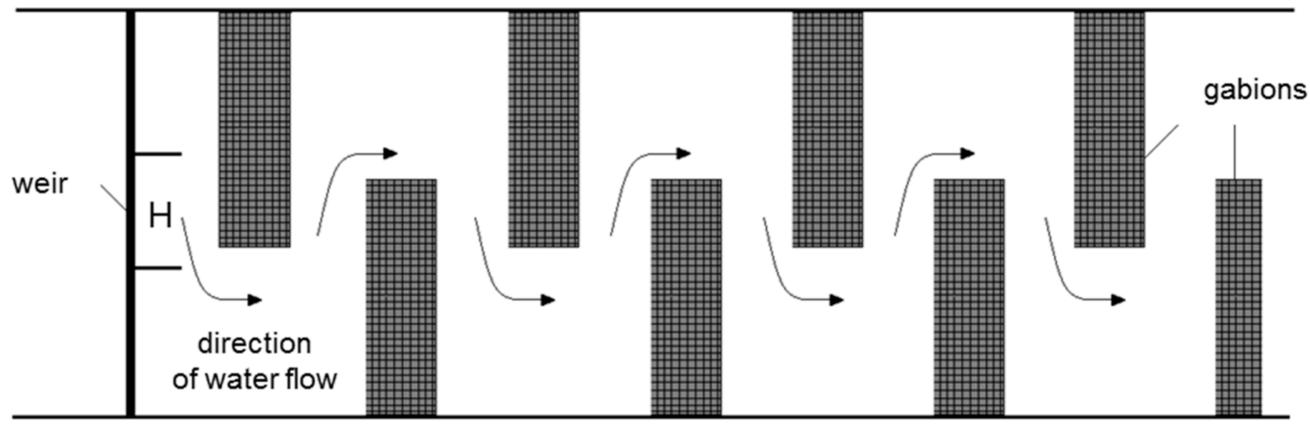

Figure 7. Crosswise arrangement of the treatment system for hypolimnetic water using reactive materials. H: outlet of the hypolimnion withdrawal pipe.

In both described arrangements, the placement of the reactive materials in the riverbed will result in a reduced river width and, thus, increased water level. To avoid flooding of the surrounding area, it is necessary to properly design the height of the gabions. Moreover, the designed structures should not be wider than $75 \%$ of the riverbed width to maintain fish migration [69]. A disadvantage of the described solutions is that probably only part of the material volume in gabions will be available for the flowing water, due to limited penetration, and some of the reactive surface will not be used, especially in the inner part of the gabions.

The induction of more intense water flowing through the gabions is possible by spraying the hypolimnetic water over the filter bed (Figure 8). For this purpose, discharged water must be directed onto the bed. This requires the placing of the filter bed out of the river, possibly close to the hypolimnion discharge. A mixture of LECA and limestone (50\%:50\%) should be used to ensure the high hydraulic conductivity of the treatment bed. Drainage tubes located at the bottoms of the gabions will collect the treated water and re-direct it into the river. The retention time may be adjusted by the size of the filter bed.

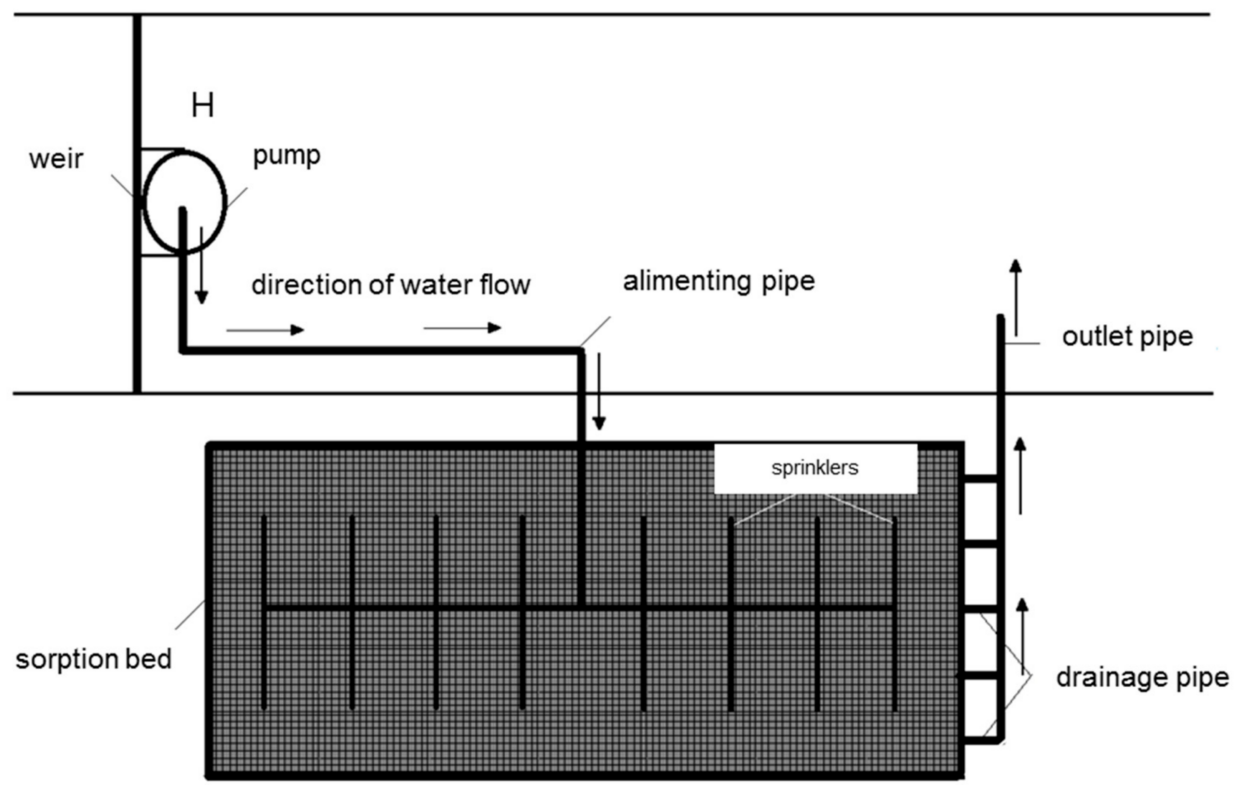

Figure 8. Separate filter bed for the treatment of hypolimnetic water using reactive materials. H: outlet of the hypolimnion withdrawal pipe.

The proposed solutions differ in gabion arrangements, which affects the contact time of the treated water with the reactive materials and the sorption of P. However, in such systems, on a technical scale, other processes of $\mathrm{P}$ removal are also involved, including microbiological transformations in biofilms developed on the filter bed [40]. The efficiency of 
the treatment is also affected by meteorological conditions (temperature and precipitation) and the composition of the treated water. It is recommended to design integrated water pretreatment systems that will employ both abiotic (sorption materials) and biological processes (aquatic plants). The natural environment is a sensitive ecosystem, where the implementation of any water treatment method must involve a detailed analysis considering both the effectiveness of the process and its influence on the aquatic environment.

The results presented in this study and the concept of different solutions for hypolimnetic water treatment are the first stage of the research. A full confirmation of the effectiveness of the proposed solutions will be possible after a study on a technical scale.

\subsection{Possible Reuse of Reactive Materials}

The reuse of once-used reactive materials is an important issue in terms of circular economy, as it could help avoid the generation of waste materials. Another urgent point is $\mathrm{P}$ recycling, as it could reduce the pressure on nonrenewable $\mathrm{P}$ resources. These two problems have received more and more attention, and the need to develop reuse and/or recycling strategies has been recognized [25,70-73]. Reuse and/or recycling is especially desirable in the case of materials whose production involves high-energy inputs, such as LECA [73].

The recovery of $\mathrm{P}$ requires its separation from the reactive material. Chemically adsorbed OP can be desorbed from LECA and LS. The desorption of OP from LECA to distilled water can be as high as $42 \%$ [45], whilst the desorption of OP from calcite (main component of LS) reaches $100 \%$ in calcite-equilibrated solutions [47,49]. However, $\mathrm{OP}$ precipitation with $\mathrm{Ca}$ is another possible mechanism of OP removal onto Ca-bearing mineral aggregates due to the dissolution of Ca compounds serving as the Ca source [58,74], although it typically requires high OP concentrations and a long contact time [35]. In that case, $\mathrm{P}$ recovery would probably require the use of a strongly acidic extraction agent (to dissolve $\mathrm{Ca}-\mathrm{PO}_{4}$ ) and further chemical $\mathrm{P}$ precipitation from the obtained solution. However, under freshwater-relevant OP concentrations, the amount of $P$ sorbed by the mass of the medium is relatively low [44,45]; hence, the P elution from these sorbents after the treatment of hypolimnetic water is a rather unlikely option for efficient and cost-effective $P$ recovery [71]. Therefore, their direct reuse is probably a more reasonable approach. This seems to be valid mainly for LECA, as this medium is widely applied as a soil conditioner for improved soil aeration and moisture retention. LECA enriched with previously sorbed $\mathrm{P}$ could offer an additional fertilizing effect. The reuse of LECA for fertilization and soil amendment for acidic soils has been suggested by previous studies [26,27]. However, the plant availability of $P$ sorbed by LECA is very limited due to a strong OP fixation by $\mathrm{Al} / \mathrm{Fe}$ oxides [70]. Ca-bound $\mathrm{P}$ shows a wide range of plant availabilities, depending on the type of calcium-phosphate formed [75], and their fertilization efficiency is mainly reported in acidic soils [76,77]. Hence, limestones and Ca-rich LECA materials represent some options for reuse as acid soil fertilizers, but this application will also unavoidably raise the soil $\mathrm{pH}$, limiting, to some extent, the $\mathrm{P}$ availability for plants. Moreover, a direct application of LS is not possible due to the coarse grains of the material, so its processing by crushing would be required, increasing the time and expenditures needed to make it suitable for use in soils. The direct application of P-enriched LECA (without further processing) for its conventional use as soil amendment seems to be the most likely to implement in practice, even though its fertilizing role would probably be minor.

The reuse of reactive materials previously applied for the treatment of hypolimnetic water by their application in the environment seems to be less restricted as compared to reactive materials used for wastewater treatment. In the latter case, the risk of heavy metals and other pollutants or pathogens (such as Escherichia coli) presence in the sorbent is somehow the limiting factor [73]. In natural waters, such as lakes' hypolimnion, this should not be the case. Even though E. coli is often present in the surface layers of lakes during bathing season, this does not influence the sanitary status of the hypolimnion due to 
thermal stratification. Heavy metals can be problematic in hardly contaminated water bodies, as metals often accumulate in sediments and can be released to the hypolimnion.

\section{Conclusions}

Our study revealed that the treatment of hypolimnetic water on sorption beds made of LECA and LS can be a useful method of OP removal. The highest OP removal success ( $>50 \%$ ) was achieved when the LECA beds were amended with a high volume of LS (75\%). Thus, a combined bed made of LECA and LS at a volumetric ratio of 1:3 is recommended as a treatment method for the purification of hypolimnetic water. The fact that the tested sorption materials did not cause negative effects on the $\mathrm{pH}$ of the water suggests that these materials can be safely employed for potential application in the environment. A slight removal of nitrogen can be also gained on sorption beds made of LECA and LS. According to our calculations, in real-life conditions, it is not feasible to install a fully dimensional bed on the outflow from a lake due to the large size required for satisfactory OP removal. Hence, the proposed bed should be just one of the elements of an integrated treatment system consisting of abiotic (sorption materials) and biotic (aquatic plants similar to constructed wetlands) elements. The performance of a potential treatment system based on LECA and LS needs further investigations on a technical scale. The results of the study are an important contribution to innovative solutions for the improvement of the ecological state of water ecosystems. This is in accordance with the Water Framework Directive of the European Union, which requires the achievement of the good ecological status of water bodies in all the member countries by 2027.

Author Contributions: Conceptualization, J.Ł.; J.A.D. and A.B.-S.; methodology, J.Ł.; J.A.D. and A.B.-S.; validation, J.A.D.; A.B.-S.; L.Z. and W.J.M.; formal analysis, J.E.; J.A.D. and A.B.-S.; investigation, J.Ł.; J.A.D. and A.B.-S.; resources, J.Ł.; J.A.D. and A.B.-S.; data curation, J.Ł.; J.A.D. and A.B.-S.; writing-original draft preparation, J.A.D.; A.B.-S. and J.Ł.; writing-review and editing, A.B.-S.; J.A.D.; L.Z. and W.J.M.; visualization, J.Ł.; supervision, J.A.D.; A.B.-S.; L.Z. and W.J.M.; project administration, J.A.D. and funding acquisition, J.A.D. All authors have read and agreed to the published version of the manuscript.

Funding: This research was funded by The Ministry of Science and Higher Education of Poland (grant number 18.610.007-300) and the European Union Under the European Social Fund (Operational Program Knowledge Education Development) within the project Development Program at the University of Warmia And Mazury In Olsztyn (POWR.03.05. 00-00-Z310/17). The APC was funded by The Ministry of Science and Higher Education of Poland (grant number 29.690.021-110).

Institutional Review Board Statement: Not applicable.

Informed Consent Statement: Not applicable.

Data Availability Statement: The data presented in this study are available on request from the corresponding author.

Acknowledgments: We kindly thank the company Weber Leca ${ }^{\circledR}$, Saint-Gobain Construction Products Poland Ltd. (Gniew) oraz Lhoist Poland Ltd. (Tarnów Opolski) for providing the mineral aggregates and the Polish Geological Institute-National Research Institute for the surface area determination and XRD analysis of the aggregates. Konrad Stawecki (The Stanislaw Sakowicz Inland Fisheries Institute, Olsztyn, Poland) is greatly acknowledged for the chromatographic measurements. The final version of this publication was prepared during the internship of Julita Dunalska in The Everglades Wetland Research Park (EWRP) in Naples, Florida, USA.

Conflicts of Interest: The authors declare no conflict of interest.

\section{References}

1. Cooke, G.; Welch, E.; Peterson, S.; Nichols, S. Restoration and Management of Lakes and Reservoirs, 3rd ed.; Taylor \& Francis: Boca Raton, FL, USA, 2005.

2. Hamilton, D.P.; Collier, K.J.; Quinn, J.M.; Howard-Williams, C. Lake Restoration Handbook A New Zealand Perspective; Springer: Berlin/Heidelberg, Germany, 2018. 
3. Jørgensen, S.E.; Jørgensen, L.A. Ecotechnological Approaches to the Restoration of Lakes. In Ecological Engineering: An Introduction to Ecotechnology; Mitsch, W.J., Jørgensen, S.E., Eds.; John and Wiley Sons: Hoboken, NJ, USA, 1989; pp. 357-374.

4. Mitsch, W.J.; Jørgensen, S.E. Ecological Engineering and Ecosystem Restoration; John and Wiley Sons Inc.: Hoboken, NJ, USA, 2004; p. 41.

5. Hamilton, D.P.; Dada, A. Lake Management: A Restoration Perspective. In Advances in New Zealand Freshwater Science; Jellyman, P.G., Davie, T.L.A., Pearson, C.P., Harding, J.S., Eds.; New Zealand Freshwater Sciences Society and New Zealand Hydrological Society: Wellington, New Zealand, 2016; pp. 531-552.

6. Mackay, E.; Maberly, S.; Pan, G.; Kasper Reitzel Department of Biology University of Southern Denmark Odense M Denmark; Bruere, A.; Corker, N.; Douglas, G.B.; Egemose, S.; Hamilton, D.P.; Hatton-Ellis, T.; et al. Geoengineering in lakes: Welcome attraction or fatal distraction? Inland Waters 2014, 4, 349-356. [CrossRef]

7. Moss, B.; Carvalho, L.; Plewes, J. The lake at Llandrindod Wells?a restoration comedy? Aquat. Conserv. Mar. Freshw. Ecosyst. 2002, 12, 229-245. [CrossRef]

8. Dunalska, J.A.; Wiśniewski, G.; Mientki, C. Assessment of multi-year (1956-2003) hypolimnetic withdrawal from Lake Kortowskie, Poland. Lake Reserv. Manag. 2007, 23, 377-387. [CrossRef]

9. Dunalska, J.; Staehr, P.A.; Jaworska, B.; Górniak, D.; Gomułka, P. Ecosystem metabolism in a lake restored by hypolimnetic withdrawal. Ecol. Eng. 2014, 73, 616-623. [CrossRef]

10. Kostecki, M. The restoration of the Plawniowice anthropogenic reservoir by hypolimnetic withdrawal. Inżynieria Ochr. Sr. 2012, 15, 101-117. (In Polish)

11. Lathrop, R.C.; Astfalk, T.J.; Panuska, J.C.; Marshall, D.W. Restoration of a Wisconsin (USA) seepage lake by hypolimnetic withdrawal. Verh. Int. Ver. Limnol. 2005, 29, 482-487. [CrossRef]

12. Nürnberg, G.K. Hypolimnetic withdrawal as a lake restoration technique: Determination of feasibility and continued benefits. Hydrobiologia 2020, 847, 4487-4501.

13. Nürnberg, G. Lake responses to long-term hypolimnetic withdrawal treatments. Lake Reserv. Manag. 2007, 23, 388-409. [CrossRef]

14. Dunalska, J. Influence of limited water flow in a pipeline on the nutrients budget in a lake restored by hypolimnetic withdrawal method. Pol. J. Environ. Stud. 2002, 11, 631-637.

15. Dunalska, J.A. Impact of limited water flow in a pipeline on the thermal and oxygen conditions in a lake restored by hypolimnetic withdrawal method. Pol. J. Environ. Stud. 2003, 12, 409-415.

16. Silvonen, S.; Niemistö, J.; Csibrán, A.; Jilbert, T.; Torma, P.; Krámer, T.; Nurminen, L.; Horppila, J. A biogeochemical approach to evaluate the optimization and effectiveness of hypolimnetic withdrawal. Sci. Total Environ. 2020, 755, 2, in press. [CrossRef] [PubMed]

17. Dunalska, J.; Rosankiewicz, A.; Grzybowska, I. Influence of the hypolimnion water withdrawal from Lake Kortowskie on the Kortówka River. Pol. Nat. Sci. 2003, 13, 159-167.

18. Tandyrak, R.; Gołaś, I.; Parszuto, K.; Bowszys, M.; Szymański, D.; Harnisz, M.; Brudniak, A.; Wysocka, I. The effect of lake restoration by the hypolimnetic withdrawal method on the intensity of ambient odour. J. Limnol. 2016, 75, 531-544. [CrossRef]

19. Kadlec, R.H.; Wallace, S. Treatment Wetlands; CRC Press: Boca Raton, FL, USA, 2008.

20. Jóźwiakowski, K.; Gajewska, M.; Pytka, A.; Marzec, M.; Gizińska-Górna, M.; Jucherski, A.; Walczowski, A.; Nastawny, M.; Kamińska, A.; Baran, S. Influence of the particle size of carbonate-siliceous rock on the efficiency of phosphorous removal from domestic wastewater. Ecol. Eng. 2017, 98, 290-296. [CrossRef]

21. Vymazal, J. Removal of nutrients in various types of constructed wetlands. Sci. Total Environ. 2007, 380, 48-65. [CrossRef]

22. Jóźwiakowski, K.; Bugajski, P.; Mucha, Z.; Wójcik, W.; Jucherski, A.; Nastawny, M.; Siwiec, T.; Mazur, A.; Obroślak, R.; Gajewska, M. Reliability and efficiency of pollution removal during long-term operation of a one-stage constructed wetland system with horizontal flow. Sep. Purif. Technol. 2017, 187, 60-66. [CrossRef]

23. Obarska-Pemkowiak, H.; Gajewska, M.; Wojciechowska, E.; Obarska-Pempkowiak, H. Application of Vertical Flow Constructed Wetlands for Highly Contaminated Wastewater Treatment: Preliminary Results. In Water and Nutrient Management in Natural and Constructed Wetlands; Springer Science and Business Media LLC: Berlin, Germany, 2010; pp. 37-50.

24. Dunalska, J.A. Abiotic-biotic method of water treatment in a shore of the lake-A new strategy for protection of urban lakes. Ecohydrol. Hydrobiol. 2018, 18, 454-458. [CrossRef]

25. Kasprzyk, M.; Gajewska, M. Phosphorus removal by application of natural and semi-natural materials for possible recovery according to assumptions of circular economy and closed circuit of P. Sci. Total Environ. 2019, 650, 249-256. [CrossRef]

26. Westholm, L.J. Substrates for phosphorus removal-Potential benefits for on-site wastewater treatment? Water Res. 2006, 40, 23-36. [CrossRef]

27. Vohla, C.; Kõiv, M.; Bavor, H.J.; Chazarenc, F.; Mander, Ü. Filter materials for phosphorous removal from wastewater in treatment wetlands-A review. Ecol. Eng. 2001, 37, 70-89. [CrossRef]

28. Vohla, C.; Põldvere, E.; Noorvee, A.; Kuusemets, V.; Mander, Ü. Alternative filter media for phosphorus removal in a horizontal subsurface flow constructed wetland. J. Environ. Sci. Health A 2005, 40, 1251-1264. [CrossRef] [PubMed]

29. Ádám, K.; Søvik, A.K.; Krogstad, T. Sorption of phosphorus to Filtralite $\mathrm{P}^{\circledR}$ —The effect of different scales. Water Res. 2006, 40, 1143-1154. [CrossRef] [PubMed]

30. Gajewska, M.; Jóźwiakowski, K.; Ghrabi, A.; Masi, F. Impact of influent wastewater quality on nitrogen removal rates in multistage treatment wetlands. Environ. Sci. Pollut. Res. 2014, 22, 12840-12848. [CrossRef] [PubMed] 
31. Lekang, O.-I.; Kleppe, H. Efficiency of nitrification in trickling filters using different filter media. Aquac. Eng. 2000, 21, 181-199. [CrossRef]

32. Öövel, M.; Tooming, A.; Mauring, T.; Mander, Ü. Schoolhouse wastewater purification in a LWA-filled hybrid constructed wetland in Estonia. Ecol. Eng. 2007, 29, 17-26. [CrossRef]

33. Somerville, C.; Cohen, M.; Pantanella, E.; Stankus, A.; Lovatelli, A. Small-Scale Aquaponic Food Production. Integrated Fish and Plant Farming; FAO: Rome, Italy, 2014.

34. Dotro, G.; Langergraber, G.; Molle, P.; Nivala, J.; Puigagut, J.; Stein, O.; von Sperling, M. Biological Wastewater Treatment Series Treatment Wetlands; IWA Publishing: London, UK, 2017; Volume 7.

35. Cucarella, V.; Renman, G. Phosphorus Sorption Capacity of Filter Materials Used for On-site Wastewater Treatment Determined in Batch Experiments-A Comparative Study. J. Environ. Qual. 2009, 38, 381-392. [CrossRef]

36. Chen, Z.; Chen, B.; Zhou, J.; Li, Z.; Zhou, Y.; Xi, X.; Lin, C.; Chen, G. A vertical subsurface-flow constructed wetland in Beijing. Commun. Nonlinear Sci. Numer. Simul. 2008, 13, 1986-1997. [CrossRef]

37. Frątczak, W.; Michalska-Hejduk, D.; Zalewski, M.; Izydorczyk, K. Effective phosphorous reduction by a riparian plant buffer zone enhanced with a limestone-based barrier. Ecol. Eng. 2019, 130, 94-100. [CrossRef]

38. Bus, A.; Karczmarczyk, A.; Baryła, A. Permeable Reactive Barriers for Preventing Water Bodies from a Phosphorus-Polluted Agricultural Runoff-Column Experiment. Water 2019, 11, 432. [CrossRef]

39. Izydorczyk, K.; Frątczak, W.; Drobniewska, A.; Cichowicz, E.; Michalska-Hejduk, D.; Gross, R.; Zalewski, M. A biogeochemical barrier to enhance a buffer zone for reducing diffuse phosphorus pollution-preliminary results. Ecohydrol. Hydrobiol. 2013, 13, 104-112. [CrossRef]

40. Brix, H.; Arias, C.; Del Bubba, M. Media selection for sustainable phosphorus removal in subsurface flow constructed wetlands. Water Sci. Technol. 2001, 44, 47-54. [CrossRef] [PubMed]

41. Ádám, K.; Krogstad, T.; Vråle, L.; Søvik, A.K.; Jenssen, P.D. Phosphorus retention in the filter materials shellsand and Filtralite $\mathrm{P}^{\circledR}$-Batch and column experiment with synthetic P solution and secondary wastewater. Ecol. Eng. 2007, 29, 200-208. [CrossRef]

42. Moharami, S.; Jalali, M. Removal of phosphorus from aqueous solution by Iran natural sorbents. Chem. Eng. J. 2013, 223, 328-339. [CrossRef]

43. Karczmarczyk, A.; Bus, A. Testing of reactive materials for phosphorus removal from water and wastewater-Comparative study. Ann. Wars. Univ. Life Sci.-SGGW. Land Reclam. 2014, 46, 57-67. [CrossRef]

44. Łożyńska, J.; Bańkowska-Sobczak, A.E.; Popek, Z.; Dunalska, J.A. Selection of P-reactive materials for treatment of hypolimnetic water withdrawn from eutrophic lakes. Ecohydrol. Hydrobiol. 2020, 20, 276-288. [CrossRef]

45. Yaghi, N.; Hartikainen, H. Enhancement of phosphorus sorption onto light expanded clay aggregates by means of aluminium and iron oxide coatings. Chemosphere 2013, 93, 1879-1886. [CrossRef]

46. Sawada, K.; Abdel-Aal, N.; Sekino, H.; Satoh, K. Adsorption of inorganic phosphates and organic polyphosphonate on calcite. Dalton Trans. 2003, 3, 342-347. [CrossRef]

47. Sø, H.U.; Postma, D.; Jakobsen, R.; Larsen, F. Sorption of phosphate onto calcite; results from batch experiments and surface complexation modeling. Geochim. et Cosmochim. Acta 2011, 75, 2911-2923. [CrossRef]

48. Suzuki, T.; Inomata, S.; Sawada, K. Adsorption of phosphate onto calcite. J. Chem. Soc. Faraday Trans. 1986, 82, 1733-1743. [CrossRef]

49. Millero, F.; Huang, F.; Zhu, X.; Liu, X.; Zhang, J.-Z. Adsorption and Desorption of Phosphate on Calcite and Aragonite in Seawater. Aquat. Geochem. 2001, 7, 33-56. [CrossRef]

50. Drizo, A.; Comeau, Y.; Forget, C.; Chapuis, R.P. Phosphorus Saturation Potential: A Parameter for Estimating the Longevity of Constructed Wetland Systems. Environ. Sci. Technol. 2002, 36, 4642-4648. [CrossRef] [PubMed]

51. Łożyńska, J. Using Mineral Aggregates to Phosphorus Removal from Hypolimnion Water Withdrawal on River. Ph.D. Thesis, University of Warmia and Mazury in Olsztyn, Department of Water Protection Engineering, Olsztyn, Poland, 2019. (not published; in Polish).

52. Wang, L.; Agudo, E.R.; Putnis, C.V.; Menneken, M.; Putnis, A. Kinetics of Calcium Phosphate Nucleation and Growth on Calcite: Implications for Predicting the Fate of Dissolved Phosphate Species in Alkaline Soils. Environ. Sci. Technol. 2012, 46, 834-842. [CrossRef] [PubMed]

53. Klasa, J.; Agudo, E.R.; Wang, L.; Putnis, C.V.; Valsami-Jones, E.; Menneken, M.; Putnis, A. An atomic force microscopy study of the dissolution of calcite in the presence of phosphate ions. Geochim. et Cosmochim. Acta 2013, 117, 115-128. [CrossRef]

54. Valsami-Jones, E. Mineralogical controls on phosphorus recovery from wastewaters. Miner. Mag. 2001, 65, 611-620. [CrossRef]

55. Mekmene, O.; Quillard, S.; Rouillon, T.; Bouler, J.-M.; Piot, M.; Gaucheron, F. Effects of pH and Ca/P molar ratio on the quantity and crystalline structure of calcium phosphates obtained from aqueous solutions. Dairy Sci. Technol. 2009, 89, 301-316. [CrossRef]

56. Bańkowska-Sobczak, A.E.; Blazejczyk, A.; Eiche, E.; Fischer, U.; Popek, Z. Phosphorus Inactivation in Lake Sediments Using Calcite Materials and Controlled Resuspension-Mechanism and Efficiency. Minerals 2020, 10, 223. [CrossRef]

57. Khadhraoui, M.; Watanabe, T.; Kuroda, M. The effect of the physical structure of a porous Ca-based sorbent on its phosphorus removal capacity. Water Res. 2002, 36, 3711-3718. [CrossRef]

58. Qin, Z.; Shober, A.L.; Scheckel, K.G.; Penn, C.J.; Turner, K.C. Mechanisms of Phosphorus Removal by Phosphorus Sorbing Materials. J. Environ. Qual. 2018, 47, 1232-1241. [CrossRef] 
59. Renman, A.; Renman, G. Long-term phosphate removal by the calcium-silicate material Polonite in wastewater filtration systems. Chemosphere 2010, 79, 659-664. [CrossRef]

60. Karczmarczyk, A.; Woja, K.; Bliska, P.; Baryła, A.; Bus, A. The efficiency of filtration materials (Polonite ${ }^{\circledR}$ and Leca ${ }^{\circledR}$ ) supporting phosphorus removal in on site treatment systems with wastewater infiltration. Infrastruct. Ecol. Rural Areas 2017, 4, 1401-1413.

61. Corman, J.R.; Moody, E.K.; Elser, J.J. Stoichiometric impact of calcium carbonate deposition on nitrogen and phosphorus supplies in three montane streams. Biogeochemistr 2015, 126, 285-300. [CrossRef]

62. Corman, J.R.; Moody, E.K.; Elser, J.J. Calcium carbonate deposition drives nutrient cycling in a calcareous headwater stream. Ecol. Monogr. 2016, 86, 448-461. [CrossRef]

63. Hamilton, S.K.; Bruesewitz, D.A.; Horst, G.P.; Weed, D.B.; Sarnelle, O. Biogenic calcite-phosphorus precipitation as a negative feedback to lake eutrophication. Can. J. Fish. Aquat. Sci. 2009, 66, 343-350. [CrossRef]

64. Ostrofsky, M.; Miller, C. Photosynthetically-mediated calcite and phosphorus precipitation by submersed aquatic vascular plants in Lake Pleasant, Pennsylvania. Aquat. Bot. 2017, 143, 36-40. [CrossRef]

65. Ali, M.; Okabe, S. Anammox-based technologies for nitrogen removal: Advances in process start-up and remaining issues. Chemosphere 2015, 141, 144-153. [CrossRef]

66. Gilbert, E.M.; Agrawal, S.; Schwartz, T.; Horn, H.; Lackner, S. Comparing different reactor configurations for Partial Nitritation/Anammox at low temperatures. Water Res. 2015, 81, 92-100. [CrossRef]

67. Van Hulle, S.W.; Vandeweyer, H.J.; Meesschaert, B.D.; Vanrolleghem, P.A.; Dejans, P.; Dumoulin, A. Engineering aspects and practical application of autotrophic nitrogen removal from nitrogen rich streams. Chem. Eng. J. 2010, 162, 1-20. [CrossRef]

68. Sharifnia, S.; Khadivi, M.A.; Shojaeimehr, T.; Shavisi, Y. Characterization, isotherm and kinetic studies for ammonium ion adsorption by light expanded clay aggregate (LECA). J. Saudi Chem. Soc. 2016, 20, S342-S351. [CrossRef]

69. Wierzbicki, M. Aspects of the fish migration trough barrages restoration in river channels. Landf. Anal. 2013, 24, 107-113. [CrossRef]

70. Hylander, L.D.; Siman, G. Plant availability of phosphorus sorbed to potential wastewater treatment materials. Biol. Fertil. Soils 2001, 34, 42-48. [CrossRef]

71. Wendling, L.A.; Blomberg, P.; Sarlin, T.; Priha, O.; Arnold, M. Phosphorus sorption and recovery using mineral-based materials: Sorption mechanisms and potential phytoavailability. Appl. Geochem. 2013, 37, 157-169. [CrossRef]

72. Gubernat, S.; Masłoń, A.; Czarnota, J.; Koszelnik, P. Reactive Materials in the Removal of Phosphorus Compounds from Wastewater-A Review. Materials 2020, 13, 3377. [CrossRef] [PubMed]

73. Mlih, R.; Bydalek, F.; Klumpp, E.; Yaghi, N.; Bol, R.; Wenk, J. Light-expanded clay aggregate (LECA) as a substrate in constructed wetlands-A review. Ecol. Eng. 2020, 148. [CrossRef]

74. Lyngsie, G.; Penn, C.J.; Hansen, H.C.B.; Borggaard, O.K. Phosphate sorption by three potential filter materials as assessed by isothermal titration calorimetry. Phosphate Sor J. Environ. Manag. 2014, 143, 26-33. [CrossRef] [PubMed]

75. Römer, W. Verleichende untersuchungen zue pflanzenverfügbarkeit von phosphat aus verschiedenen P-recycling-produkten im Keimpflanzenversuch. J. Plant Nutr. Soil Sci. 2006, 169, 826-832. [CrossRef]

76. Bauer, P.J.; Szogi, A.A.; Vanotti, M.B. Agronomic Effectiveness of Calcium Phosphate Recovered from Liquid Swine Manure. Agron. J. 2007, 99, 1352-1356. [CrossRef]

77. Cabeza, R.A.; Steingrobe, B.; Römer, W.; Claassen, N. Effectiveness of recycled P products as P fertilizers, as evaluated in pot experiments. Nutr. Cycl. Agroecosyst. 2011, 91, 173-184. [CrossRef] 